\title{
Effect of Tetrathionate on the Growth of a Marine Thiobacillus
}

\author{
By J. R. MURPHY*, J. M. KORNFELD AND R. C. TILTON \\ University of Connecticut Health Centre, Hartford, Connecticut, 06105, U.S.A.
}

(Received 21 September 197I; revised I6 June 1972)

\begin{abstract}
SUMMARY
Thiobacillus sp. strain IV-85, an isolate from the marine environment, oxidized thiosulphate in two sequential logarithmic phases. Tetrathionate accumulated in the partially spent broth during the first logarithmic phase, and reached a maximum concentration at the time of transition to the second logarithmic phase. Tetrathionate added during the early first logarithmic phase caused a decrease in the rate of thiosulphate utilization similar to that observed after the transition from the first to second logarithmic phase. Bacteria harvested from the first logarithmic phase resisted $0 \cdot 1 \mathrm{mM}$-cyanide which inhibited oxygen uptake by bacteria harvested from the second logarithmic phase. Rhodanese (thiosulphate: cyanide sulphur transferase, EC. 2.8. I. I) was detected in extracts of bacteria from both phases. Tetrathionate accumulation in the growth medium inhibited rhodanese activity, resulting in the transition of thiosulphate utilization from the first to second logarithmic phase.
\end{abstract}

\section{INTRODUCTION}

The production of polythionates by thiobacilli during thiosulphate oxidation has been widely reported in the literature. Tetrathionate accumulation has been reported for Thiobacillus thioparus (London \& Rittenberg, 1964), T. neapolitanus (Parker \& Prisk, 1953), T. thiooxidans (Okuzumi \& Kita, I965), T. denitrificans (Woolley, Jones \& Happold, I962) and T.novellus (Vishniac \& Trudinger, 1962). Conditions necessary for polythionate accumulation vary widely. Santer, Margulies, Klinman \& Kaback (1960) indicated that polythionates only accumulate in the absence of inorganic phosphate. Trudinger (I964) reported that polythionates accumulated in the growth medium of $T$. neapolitanus only under conditions of low aeration. In their taxonomic study of the thiobacilli, Hutchinson, Johnstone \& White (1969) reported that, in general, inhibitory conditions tended to produce an incomplete metabolism of thiosulphate to tetrathionate.

Murphy, Kornfeld \& Tilton (1971) have described the biphasic utilization of thiosulphate by the marine isolate IV-85, a species of Thiobacillus. The effect of tetrathionate accumulation on thiosulphate utilization is reported here.

\section{METHODS}

Thiobacillus sp. strain IV-85 was maintained in thiosulphate salts broth supplemented with $50 \%$ synthetic sea water as previously described (Murphy et al. 1971). For experiments, the organism was cultured in $\mathrm{I} . \mathrm{O} 1$ medium sparged with a mixture of $3.3 \% \mathrm{CO}_{2}, 10.5 \% \mathrm{O}_{2}$, $2 \mathrm{I} \cdot 5 \% \mathrm{~N}_{2}$ and $64.7 \% \mathrm{He}$ at a rate of $720 \mathrm{ml} / \mathrm{min}$ and shaken at $20{ }^{\circ} \mathrm{C}$.

Thiosulphate was determined by iodine titration using starch as indicator. Polythionates in the partially spent medium were detected by thin-layer chromatography on Eastman cellulose chromatogram sheets (Distillation Products Industries, Rochester, New York, U.S.A.) developed by an ascending solvent system of glycerol $+n$-butanol + acetone + water

\footnotetext{
* Present address: The Biological Laboratories, Harvard University, Cambridge, Massachusetts, U.S.A.
} 


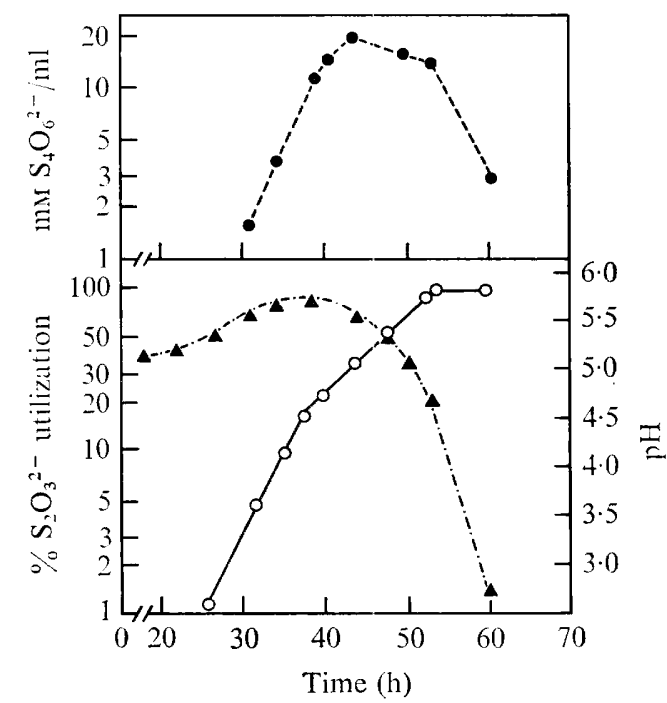

Fig. I

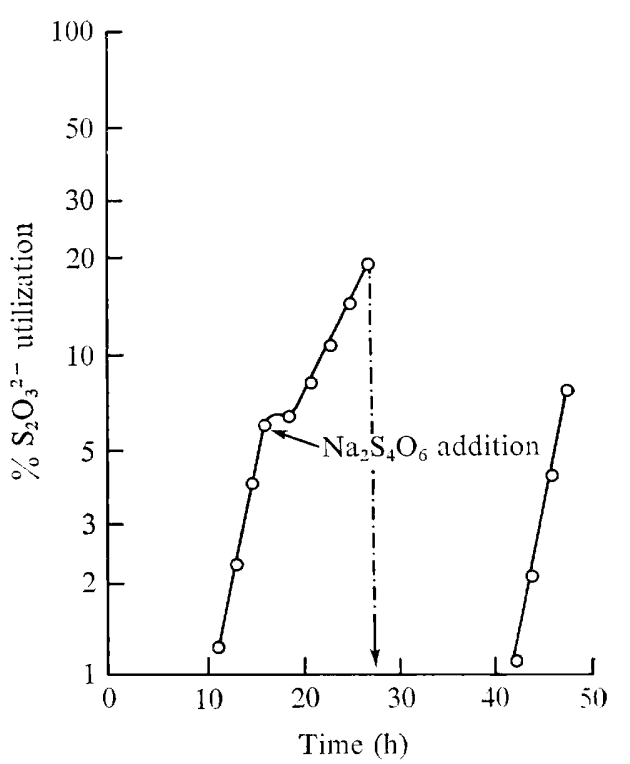

Fig. 2

Fig. I. Comparison of tetrathionate accumulation (๑), $\mathrm{pH}(\mathbf{\Delta})$ and thiosulphate utilization $(O)$ during the growth of Thiobacillus sp. strain IV-85.

Fig. 2. The effect of tetrathionate addition on thiosulphate utilization during first logarithmic phase growth of Thiobacillus sp. strain IV-85.

+ ammonium hydroxide (5:35:30:30:2.5; Tano, Asano \& Imai, 1968) and visualized with ammonical silver nitrate spray. The accumulation of polythionates was determined quantitatively by the method of Starkey (I934). Bacteria were counted in a Petroff-Hausser counting chamber.

The oxidation of thiosulphate in the presence of cyanide was measured at $20{ }^{\circ} \mathrm{C}$ in a Differential Respirometer (Gilson Medical Electronics, Middleton, Wisconsin, U.S.A.). The reaction vessels contained: $\mathrm{Na}_{2} \mathrm{~S}_{2} \mathrm{O}_{3}, 0 . \mathrm{I} \mathrm{M} ; \mathrm{KH}_{2} \mathrm{PO}_{4}, 67 \mathrm{mM} ; \mathrm{KCN}$, o. I mM; bacterial suspension, $\mathrm{I} \cdot 0 \mathrm{ml}$; and synthetic sea water:deionized water $(\mathrm{I}: \mathrm{I}, \mathrm{v} / \mathrm{v})$ to $3.0 \mathrm{ml}, \mathrm{pH}$ adjusted to 5.5 . The centre well contained $0 . \mathrm{I} \mathrm{ml} 20 \% \mathrm{KOH}$. After equilibration, thiosulphate and cyanide were added from side arms.

Cell free extracts were prepared from 101 culture grown at $20^{\circ} \mathrm{C}$ in a New Brunswick Microferm Fermentor (New Brunswick Scientific Co., New Brunswick, New Jersey, U.S.A.), agitated at $500 \mathrm{rev} . / \mathrm{min}$ and sparged with air at $41 / \mathrm{min}$. Bacteria were harvested by continuous flow centrifugation, suspended in 67 mM-sodium phosphate buffer, $\mathrm{pH} 8 \cdot \mathrm{I}$, and the accumulated sulphur removed by slow-speed centrifugation. The bacterial suspension was washed three times, resuspended at $25 \%(\mathrm{w} / \mathrm{v})$ in potassium phosphate buffer, and disrupted in a Bronwill Biosonik cell disintegrator at maximum power for $15 \mathrm{~min}$. Whole bacteria and debris were removed at $18000 \mathrm{~g}$ for $10 \mathrm{~min}$ to provide a crude cell-free extract. Total protein was measured according to Lowry, Rosebrough, Farr \& Randall (I95I).

Rhodanese activity was determined according to the method of Bowen, Butler \& Happold (I965), which measures the appearance of thiocyanate from thiosulphate and cyanide, and by the method of Smith \& Lascelles (1966), which measures the formation of sulphite from thiosulphate and cyanide by coupling it to the reduction of dichloroindophenol (DCIP) in the presence of methylphenazonium methosulphate (PMS). 


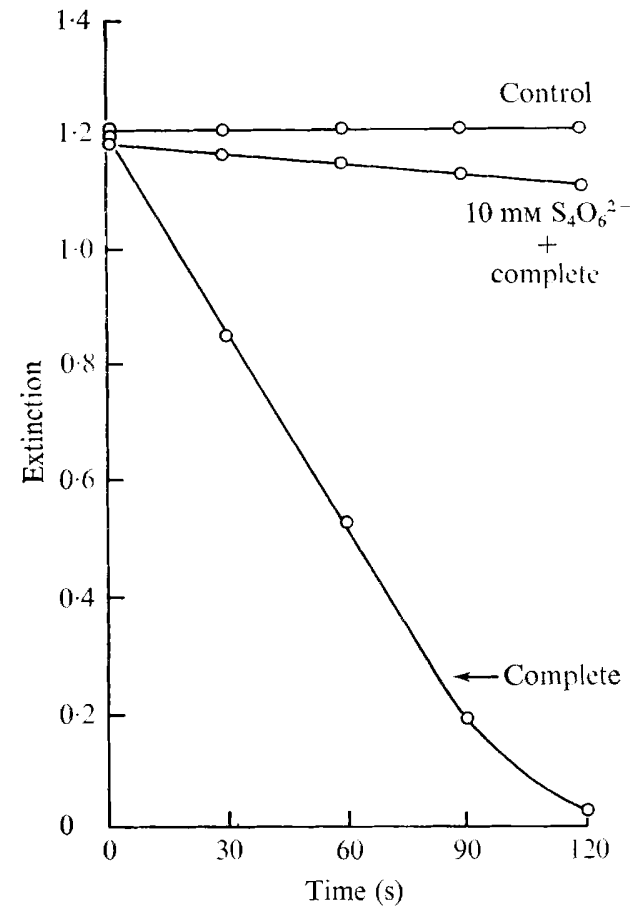

Fig. 3. The inhibition of rhodanese activity in cell-free extracts of Thiobacillus sp. strain IV-85 by Io mm-tetrathionate.

\section{RESULTS AND DISCUSSIONS}

In order to prolong the first logarithmic phase of growth, cultures were sparged with the gas mixture described. Thiosulphate utilization and total count of Thiobacillus strain IV-85 were characterized by two sequential logarithmic phases. A full log plot of thiosulphate utilization against total cell count showed a direct correlation between thiosulphate utilization and growth.

In both the first and second logarithmic phases tetrathionate was the only polythionate detected in the medium. During the first logarithmic phase a rapid increase in tetrathionate concentration was accompanied by a rise in $\mathrm{pH}$ (Fig. I). Tetrathionate may therefore have caused the second logarithmic phase, so it was added directly to an early first logarithmic phase culture at the concentration observed at the transition point. After an initial inhibition of thiosulphate utilization, thiosulphate disappearance was comparable to that of the second logarithmic phase of growth (Fig. 2). Ten hours after the addition of tetrathionate a sample of the culture medium was withdrawn, the bacteria were removed by centrifugation, washed twice in phosphate buffer $(0.067 \mathrm{M}, \mathrm{pH} 5.5)$, and a second flask containing fresh medium inoculated with the washed bacteria at a density equivalent to that of the original inoculum. After a short lag, thiosulphate utilization proceeded at a rate comparable to that of the first logarithmic phase. Hence tetrathionate is directly involved in the transition from first to second logarithmic phase. Consistent with this hypothesis, inocula taken from the first logarithmic phase by centrifugation and used to inoculate fresh medium maintained first logarithmic phase, indicating that the first logarithmic phase could be maintained if tetrathionate was not allowed to accumulate. 

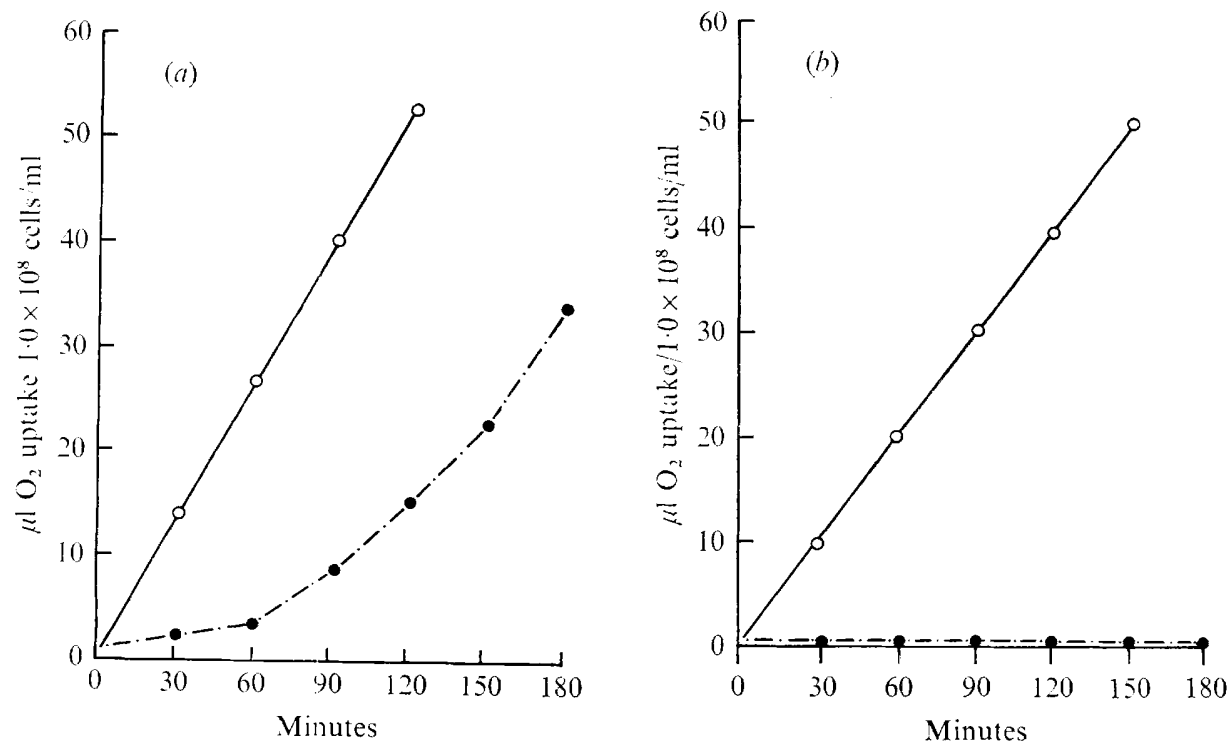

Fig. 4. (a) The effect of 0.I mM-KCN on oxygen uptake by first logarithmic phase Thiobacillus sp. strain IV-85; O, without KCN; $\bullet$, with KCN. Corrected for endogenous control. $(b)$ The effect of o.I mM-KCN on oxygen uptake by second logarithmic phase Thiobacillus sp. strain IV-85: $\mathrm{\text {, }}$ without $\mathrm{KCN}$;, , with KCN. Corrected for endogenous control.

Smith \& Lascelles (I966) reported that rhodanese (thiosulphate: cyanide sulphurtransferase), which had been partially purified from Chromatium vinosum, was completely inhibited by io to $40 \mathrm{~mm}$-tetrathionate. This enzyme catalyses the following reaction:

$$
\mathrm{S}_{2} \mathrm{O}_{3}{ }^{2-}+\mathrm{CN}^{-}-\mathrm{SCN}^{-}+\mathrm{SO}_{3}{ }^{2-}
$$

(Lang, 1933) and a thiosulphate-lipoate oxidation reduction reaction:

$$
\mathrm{S}_{2} \mathrm{O}_{3}{ }^{2-}+\text { lipoate }(\mathrm{SH})_{2}-\mathrm{HS}^{-}+\text {lipoate }\left(\mathrm{S}_{2}\right)+\mathrm{SO}_{3}{ }^{2-}+\mathrm{H}^{+}
$$

(Villarejo \& Westley, 1963). Extracts of Thiobacillus strain IV-85 showed a rhodanese activity of $26.3 \mu \mathrm{g} \mathrm{SCN}^{-} \mathrm{min}^{-1} \mathrm{mg}^{-1}$. Fig. 3 shows the inhibition of rhodanese activity by Io mM-tetrathionate, the same concentration of tetrathionate as that observed at the time of transition from the first to second logarithmic phase.

Since a role in cyanide detoxification has been repeatedly stressed for rhodanese, the effect of cyanide as a respiratory inhibitor on bacteria harvested from the first and second logarithmic phase was examined. At O.I mM, cyanide temporarily inhibited oxygen uptake by first logarithmic phase bacteria, but after 60 min oxygen uptake accelerated to approximately that of the control (Fig. $4 a$ ). In contrast, oxygen uptake by second logarithmic phase bacteria was completely inhibited by 0.1 mM-cyanide (Fig. $4 b$ ). This differential toxicity may be explained by proposing that the cyanide concentration used was in principle sufficient to inhibit oxygen uptake by bacteria from both logarithmic phases, but that, in the first logarithmic phase, excess cyanide could be removed by rhodanese, resulting in the formation of thiocyanate. In contrast, tetrathionate inhibition of rhodanese would prevent this detoxification in second logarithmic phase bacteria.

This investigation was supported by NSF Grant no. 6787 and a Public Health Service Predoctoral Fellowship (RR-05678-03) to J.R.M. 


\section{REFERENCES}

Bowen, T. J., Butler, P. J. \& Happold, F. C. (1965). Some properties of the rhodanese system of Thiobacillus denitrificans. Biochemical Journal 97, 651-657.

Hutchinson, M., Johnstone, K. I. \& White, D. (1969). Taxonomy of the genus Thiobacillus: the outcome of numerical taxonomy to the group as a whole. Journal of General Microbiology 57, 397-410.

LANG, K. (1933). Die Rhodanbildung im Tierkörper. Biochemische Zeitschrift 259, 243-256.

London, J. \& Rittenberg, S. C. (1964). Path of sulphur in sulphide and thiosulphate oxidation by thiobacilli. Proceedings of the National Academy of Sciences of the United States of America 52, I $83^{-1} 190$.

Lowry, O. H., Rosebrough, N. J., Farr, A. L. \& Randall, R. J. (I95I). Protein measurement with the Folin phenol reagent. Journal of Biological Chemistry I93, 265-275.

Murphy, J. R., Kornfeld, J. M. \& Tilton, R. C. (I97I). Biphasic thiosulphate utilization by a marine Thiobacillus. Journal of General Microbiology 68, $231-233$.

Okuzumi, M. \& KiтA, T. (1965). Studies on the biochemistry of the thiobacilli. VI. Oxidation of thiosulphate to tetrathionate by $T$. thiooxidans. Agricultural and Biological Chemistry 29, 1063-1068.

PARKer, C. D. \& PrISK, J. (1953). The oxidation of inorganic compounds of sulphur by various sulphur bacteria. Journal of General Microbiology 8, 344-364.

Santer, M., Margulies, M., Klinman, N. \& Kaback, R. (1960). Role of inorganic phosphate in thiosulphate metabolism by Thiobacillus thioparus. Journal of Bacteriology 79, 313-320.

Smith, A. J. \& LAsCelles, J. (I966). Thiosulphate metabolism and rhodanese in Chromatium sp. strain D. Journal of General Microbiology 42, 357-370.

STARKEY, R. L. (1934). The production of polythionates from thiosulphate by microorganisms. Journal of Bacteriology 28, 387-400.

Tano, T., Asano, H. \& ImaI, K. (1968). Physiological studies on thiobacilli. III. Oxidation of thiosulphate by particulate fraction of Thiobacillus thiooxidans. Agricultural and Biological Chemistry 32, $140-143$.

Trudinger, P. A. (1964). Oxidation of thiosulphate by intact cells of Thiobacillus X: effects of some experimental conditions. Australian Journal of Biological Science 17, 738-75I.

Villarejo, M. \& Westley, J. (1963). Rhodanese-catalysed reduction of thiosulphate by reduced lipoic acid. Journal of Biological Chemistry 238, $1185 \mathrm{PC}-1186 \mathrm{PC}$.

Vishniac, W. \& Trudinger, P. A. (1962). Symposium on autotrophy. V. Carbon dioxide fixation and substrate oxidation in the chemosynthetic sulphur and hydrogen bacteria. Bacteriological Reviews 26, $168-175$.

WoOlley, D., Jones, G. L. \& Happold, F. C. (1962). Some metabolic differences between Thiobacillus thioparus, $T$. denitrificans, and T. thiocyanoxidans. Journal of General Microbiology 29, 31 I-316. 